\title{
Peranan Guru Dalam Pendidikan Inklusif Untuk Pencapaian Program Tujuan Pembangunan Berkelanjutan (SDG's)
}

\author{
Nurul Ani Khayati ${ }^{1,}$ Faizatul Muna ${ }^{1}$, Eling Diar Oktaviani ${ }^{1}$ \& Ahmad Fauzan Hidayatullah ${ }^{2}$ \\ Fakultas Psikologi dan Kesehatan, Universitas Islam Negeri Walisongo Semarang \\ Email: ${ }^{1}$ nurulanikhayati_1807016012@students.walisongo.ac.id \\ ${ }^{1}$ faizatulmuna_1807016037@students.walisongo.ac.id \\ 1elingdiar_1807016066@students.walisongo.ac.id
}

\begin{abstract}
Abstrak
Fenomena mengenai permasalahan yang berhubungan dengan siswa berkebutuhan khusus atau siswa yang membutuhkan pengajaran dalam menuntut ilmu secara lebih mendalam. Siswa tersebut nantinya akan mengikuti sistem pembelajaran reguler terutama di Sekolah Dasar yang menuntut untuk menyelenggarakan pembelajaran secara inklusi yang menyatukan proses belajar mengajar antara siswa reguler (siswa yang normal) dengan siswa berkebutuhan khusus. Maka dari itu kompetensi Guru di Sekolah akan dituntut lebih mendalam dalam mengajar siswa yang berkebutuhan khusus. Metodologi yang digunakan dalam penelitian ini menggunakan metode kepustakaan (library research), sedangkan pengumpulan data dengan menelaah dan mengeksplorasi beberapa Jurnal, buku, serta beberapa artikel dimana sumber data atau informasi lainnya relevan (terkait) dengan kajian yang sesuai. Tujuan dari penelitian ini untuk menganalisis peranan Guru dalam Pendidikan inklusif kepada siswa yang berkebutuhan khusus. Hasil penelitian menunjukkan bahwa guru sudah melakukan pembelajaran adaptif bagi anak yang kesulitan belajar dengan menyesuaikan kondisi peserta didik itu sendiri, penyesuaian tersebut berkaitan dengan metode strategi, materi, alat/media pembelajaran, dan lingkungan belajar.
\end{abstract}

Kata-kata kunci: pendidikan; Inklusif; Guru;

\section{The Role of Teachers in Inclusive Education for Achieving the Sustainable Development Goals (SDG's) Program}

\author{
Nurul Ani Khayati ${ }^{1,}$ Faizatul Muna $^{1}$, Eling Diar Oktaviani ${ }^{1}$ \& Ahmad Fauzan Hidayatullah ${ }^{2}$ \\ Faculty of Psychology and Health, Universitas Islam Negeri Walisongo Semarang \\ Email: ${ }^{1}$ nurulanikhayati_1807016012@students.walisongo.ac.id \\ ${ }^{1}$ faizatulmuna_1807016037@students.walisongo.ac.id \\ 1elingdiar_1807016066@students.walisongo.ac.id
}

\begin{abstract}
The phenomenon of problems relating to students with special needs or students who need teaching in their studies more deeply. The student will later follow the regular learning system, especially in elementary schools, which demand to hold inclusive learning that unites the teaching and learning process between regular students (normal students) and students with special needs. Therefore the competence of teachers in schools will be demanded to be more profound in teaching students with special needs. The methodology used in this study uses the method of library (library research), while collecting data by examining and exploring a number of journals, books, and several articles where data sources or other information are relevant (related) to the appropriate study. The purpose of this study is to analyze the role of teachers in inclusive education to students with special needs. The results showed that the teacher had done adaptive learning for children who had difficulty learning by adjusting the conditions of the students themselves, the adjustment was related to the method of strategy, material, learning tools / media, and learning environment.
\end{abstract}

Keywords: education; inclusive; teacher 


\section{PENDAHULUAN}

Salah satu faktor sosial yang masih ada dan begitu memprihatinkan dimana semua orang takut mengalami hal tersebut adalah faktor sosial kemiskinan yang selalu menjadi perhatian di semua kalangan serta sudah menjadi fokus MDGs yang diprakarsai oleh Perserikatan BangsaBangsa [PBB, 1]. Tujuan dari Pembangunan Milenium (MDGs) ini di keluarkan dengan tujuan untuk mengatasi permasalahan kemiskinan global. Fokus penanganan kemiskinan berkelanjutan menjadi topik utama dalam Tujuan Pembangunan Berkelanjutan (SDGs). Beberapa titik deklarasi SDGs menyatakan "Kami menyadari bahwa memberantas kemiskinan dalam segala bentuk dan dimensi, termasuk kemiskinan yang ekstrem, merupakan tantangan. Dimana persyaratan terbesar tantangan yang sangat global yang diperlukan untuk pembangunan berkelanjutan.” (Robinson, 2017)

Anak-anak berkebutuhan khusus mempunyai kesetaraan dengan warga negara lainnya termasuk hak pendidikan. Kesetaraan hak mereka dengan warga negara lain ditegaskan dalam Pasal 31 UndangUndang Dasar 1945 yang menyatakan bahwa "Tiap-tiap warga negara berhak mendapat pengajaran". Pasal 32 ayat 1 UU No. 20/2003 memberikan batasan bahwa "Pendidikan khusus merupakan pendidikan bagi peserta didik yang memiliki tingkat kesulitan dalam mengikuti proses pembelajaran karena kelainan fisik, emosional, mental, sosial, dan/atau memiliki potensi kecerdasan dan bakat istimewa".

Bentuk dari pendidikan bagi $\mathrm{ABK}$ adalah Pendidikan Inklusi. Menurut Pasal 1 Permendiknas No. 70 tahun 2009, pendidikan Inklusi adalah sistem penyelenggaraaan pendidikan yang memberikan kesempatan kepada semua peserta didik yang memiliki kelainan dan memiliki potensi kecerdasan dan/atau bakat istimewa untuk mengikuti pendidikan atau pembelajaran dalam satu lingkungan pendidikan secara bersama-sama dengan peserta didik pada umumnya. Menurut Pasal 2 Permendiknas No. 70 tahun 2009 pasal 2, tujuan dari pendidikan Inklusif adalah: (a) memberikan kesempatan yang seluasluasnya kepada semua peserta didik yang memiliki kelainan fisik, emosional, mental dan sosial atau memiliki potensi kecerdasan dan/atau bakat istimewa untuk memperoleh pendidikan yang bermutu sesuai dengan kebutuhan dan kemampuannya. mewujudkan penyelenggaraan pendidikan yang menghargai keanekaragaman, dan tidak diskriminatif bagi semua peserta didik.

Mewujudkan pendidikan inklusif juga harus bersamaan dengan kompetensi guru dalam mengajar, dimana guru tak membedakan murid-muridnya dalam pembelajaran. Penyelenggaraan Pendidikan Inklusif melibatkan berbagai pihak untuk bisa bermanfaat secara maksimal. Pendidikan inklusif dalam 
penyelenggaraannya mengharuskan

keterlibatan pihak sekolah, masyarakat dan keluarga (Agung, 2016). Pihak sekolah yang harus dilibatkan mulai dari kepala sekolah, guru kelas, teman-teman sekolah, dan seluruh warga sekolah. Dari pihak masyarakat mulai dari tatanan paling tinggi yakni pembuat kebijakan, dan lingkungan sekitar anak serta industri sebagai tempat anak mengeksplorasi potensi setelah selesai belajar. Dari pihak keluarga sangat dibutuhkan dukungan secara material dan non-material untuk mendukung keberlangsungan pembelajaran (Supena, 2016).

Guru umum yang ada di sekolah inklusi memiliki tantangan yang berbeda dengan guru yang mengajar "anak normal". Terkait guru kelas di sekolah inklusif. Guru kelas umum dituntut untuk memiliki pengetahuan terkait kurikulum dan rancangan pembelajaran sesuai dengan karakteristik anak berkebutuhan khusus tersebut (Fannisa, 2013). Dengan demikian guru harus memahami pula karakteristik serta kelebihan dan kekurangan yang dimiliki anak berkebutuhan khusus.

\section{METODE}

Penelitian pada penulisan tesis ini menggunakan metode deskriptif analitik dengan pendekatan kualitatif. Penggunaan pendekatan ini disesuaikan dengan tujuan pokok penelitian, yaitu mendeskripsikan dan menganalisis bagaimana peranan Guru dalam sekolah Inklusif terhadap siswa yang berkebutuhan khusus.

Pada pendekatan penelitian kualitatif ini akan lebih banyak mementingkan segi proses daripada hasil, Dengan kata lain penelitian deskriptif analitis mengambil masalah atau memusatkan perhatian kepada masalahmasalah sebagaimana adanya saat penelitian dilaksanakan, hasil penelitian yang kemudian diolah dan dianalisis untuk diambil kesimpulannya.

\section{HASIL DAN PEMBAHASAN}

Indonesia menuju pendidikan inklusi secara formal dideklarasikan pada tanggal 11 Agustus 2004 di Bandung, dengan harapan dapat menggalang sekolah regular untuk mempersiapkan Pendidikan bagi semua anak termasuk difabel. Untuk mewujudkan sekolah inkusif dibutuhkan beberapa hal diantaranya: a) Kompetensi Guru Sekolah Inklusif; b) Model dan Strategi Pembelajaran oleh Guru.

\section{Kompetensi Guru Sekolah Inklusif}

Kompetensi guru adalah kemampuan mengelola pembelajaran siswasiswi berkebutuhan khusus yang terdiri atas aspek pengetahuan, pemahaman, kemampuan, nilai, sikap, dan minat, sebagai seperangkat tindakan yang cerdas, penuh tanggung jawab, yang dimiliki Guru sebagai syarat untuk dianggap mampu oleh masyarakat dalam melaksanakan tugas-tugas 
Guru (Kepmendiknas No. 045/U/2002 dalam Garnida, 2015).

Kondisi ini menuntut kompetensi Guru yang khusus dalam menangani proses pembelajaran siswa berkebutuhan khusus. Paradigma Guru yang awalnya hanya pengajar (teacher), kini beralih menjadi pelatih (coach), pembimbing (counselor) serta manajer belajar (learning manager) (Lattu, 2012). Uji kompetensi yang dikembangkan ini tidak mampu memetakan kompetensi Guru dalam menangani proses pembelajaran siswa berkebutuhan khusus yang menjadi permasalahan di lapangan. Perlu adanya data mengenai kompetensi Guru dalam pembelajaran inklusif yang saat ini tidak terakomodir dalam sistem pendidikan reguler di Sekolah Dasar meski pada kenyataannya menjadi tuntutan di lapangan. Aspek kompetensi guru tertera pada tabel 1 berikut:

Tabel 1. Aspek kompetensi guru

\begin{tabular}{ll}
\hline \multicolumn{1}{c}{ Aspek } & \multicolumn{1}{c}{ Penjelasan } \\
\hline Pengetahuan & kesadaran dalam bidang kognitif, seperti: mengetahui cara \\
(knowledge), & mengidentifikasikan kebutuhan belajar dan bagaimana melakukan \\
& pembelajaran terhadap siswa-siswi berkebutuhan khusus sesuai \\
& dengan kebutuhan juga fase perkembangannya. \\
Pemahaman & kedalaman kognitif dan afektif yang dimiliki guru dalam \\
(understanding) & melaksanakan pembelajaran, seperti: memiliki pemahaman tentang \\
& karakteristik dan kondisi siswa-siswi berkebutuhan khusus, agar \\
& dapat melaksanakan pembelajaran secara efektif dan efisien. Guru \\
& juga perlu memahami gangguan dan kemampuan belajar yang \\
& terjadi pada siswa. (Mash, 2010). \\
& Sesuatu yang dimiliki oleh Guru dalam melaksanakan tugasnya \\
& seperti memodifikasi kurikulum yang sesuai dengan kemampuan \\
& siswa-siswi berkebutuhan khusus, memilih metode yang sesuai \\
& dalam menyampaikan materi, serta mampu memilih atau membuat \\
& alat peraga sederhana untuk memberi kemudahan belajar kepada \\
& siswasiswi berkebutuhan khusus. \\
& suatu standar perilaku yang diyakini dan secara psikologis telah \\
& menyatu dalam diri seseorang, seperti: standar perilaku jujur, \\
& terbuka, demokratis, dan penghargaan terhadap perbedaan kondisi \\
& individual siswa-siswi berkebutuhan khusus. \\
Nilai (value) & peran (skill)
\end{tabular}

Sikap (attitude), perasaan (senang/tidak senang, suka/tidak suka) atau reaksi 
terhadap pembelajaran siswa-siswi berkebutuhan khusus.

Minat (interest) yaitu kecenderungan Guru untuk mempelajari atau melakukan pembelajaran bagi siswa-siswi berkebutuhan khusus. (Garnida, 2015 dan Mulyasa, 2013).

Guru juga perlu memberikan dukungan bagi siswa yang diperlukan untuk memberikan layanan kebutuhan bagi siswa berkebutuhan khusus. Pihak sekolah perlu memberikan dukungan untuk Guru supaya memiliki kesempatan latihan yang dapat digunakan dalam menangani jumlah keberagaman siswa. Kepala sekolah dan staf lain harus pula memberikan dukungan dan kepemimpinan di sekolah yang lebih inklusif. Kurikulum harus cukup fleksibel dengan pencapaian dan tujuan belajar harus diberi penilaian yang memberikan gambaran kemampuan siswa. (Garnida, 2015)

Dalam pembelajaran inklusif, peran guru sangatlah penting karena merupakan tonggak proses pembelajaran (Aline, 2010). Kegiatan pembelajaran di sekolah yang bersifat inklusi perlu memiliki kemampuan menerapkan kurikulum yang bersifat heterogen. Langkah yang perlu dipersiapkan guru dalam penyelenggaraan pendidikan inklusif adalah sebagai berikut: 1) Perencanaan pembelajaran disesuaikan dengan kebutuhan siswasiswi dengan mengacu pada kurikulum yang disesuaikan. Guru mampu menyusun rencana program pembelajaran individual (PPI) yang mampu memodifikasi kurikulum disesuaikan kemampuan anak didik; 2) Proses pembelajaran dilaksanakan sesuai dengan kondisi dan kemampuan siswasiswi yang menekankan pada proses belajar yang optimal. Pembelajaran dapat bersifat fleksibel dengan melihat pada kemajuan anak. 3) Penilaian meliputi pengukuran terhadap materi yang telah dipelajari dengan standar individual pada kemampuan dasar yang harus dikuasai. 4) Pengawasan pembelajaran dilakukan tidak hanya oleh pihak sekolah namun bekerja sama dengan orang tua dan lingkungan masyarakat. (Hamalik, 2014)

\section{Model dan Strategi Pembelajaran oleh Guru.}

Berdasarkan hasil observasi dalam sebuah penelitian, diketahui bahwa Guru sudah melakukan pembelajaran adaptif bagi anak yang kesulitan belajar yaitu pembelajaran 
yang menyesuaikan dengan kondisi siswa, maksudnya yaitumenyesuaikan dengan kondisi peserta didik itu sendiri, bukan peserta didik menyesuaikan dengan pembelajaran, yang tentunya penyesuaian tersebut berkaitan dengan metode strategi, materi, alat/media pembelajaran, dan lingkungan belajar.

Model pertama pada pembelajaran yang dilakukan oleh Guru kelas 4 dan 5 yaitu model klasikal dimana siswa normal dan berkebutuhan khusus mengikuti pembelajaran dalam satu kelas. Model kedua yaitu model pembelajaran individual dimana siswa yang mengalami kesulitan belajar/berkebutuhan khusus mendapatkan tambahan jam belajar yang biasanya dilaksanakan setelah jam pelajaran selesai.

Selain itu terdapat guru pendamping yang bertugas mendampingi guru kelas ketika di dalam pembelajaran guru kelas tersebut mengalami kesulitan.Strategi guru dalam mengajar kelas inklusi yaitu guru menyampaiakan materi pelajaran yang diselingi dengan sedikit permainan atau games. Hal ini dikarenakan siswa kelas inklusi cenderung memiliki tingkat konsentrasi yang dibawah rata-rata. Teknik evaluasi yang dilakukan oleh guru kelas dengan cara mengurangi kompetensi bagi kelas inklusi serta menurunkan tingkat materi bagi siswa. Adapun strategi atau metode yang biasa dilakukan guru seperti tanya jawab, diskusi yang dikemas menggunakan teknik-teknik yang dimiliki oleh guru kelas itu sendiri dengan menyesuaikan kondisi peserta didiknya begitu juga dengan penataan tempat duduk yang dibuat melingkar dan mengelompok. Dalam hal penilaian siswa kelas inklusi mendapatkan dua buah buku laporan siswa yaitu laporan nilai (raport) dan buku laporan perkembangan siswa.

\section{KESIMPULAN DAN SARAN}

Berdasarkan hasil pembahasan, dapat disimpulkan bahwa peranan guru dalam pendidikan inklusif harus memiliki kompetensi atau kemampuan mengelola pembelajaran siswa-siswi berkebutuhan khusus yang terdiri atas aspek pengetahuan, pemahaman, kemampuan, nilai, sikap, dan minat, sebagai seperangkat tindakan yang cerdas, penuh tanggung jawab, yang dimiliki guru sebagai syarat untuk dianggap mampu oleh masyarakat dalam melaksanakan tugastugas guru.Paradigma guru yang semula hanya pengajar (teacher), kini beralih sebagai pelatih (coach), pembimbing (counselor) dan manajer belajar (learning manager). Selain itu, dalam pembelajaran 
inklusi, peran guru sangatlah penting karena merupakan tonggak proses pembelajaran. Kegiatan pembelajaran di sekolah yang bersifat inklusi perlu memiliki kemampuan menerapkan kurikulum yang bersifat heterogen.

\section{DAFTAR PUSTAKA}

Agung, N. L. M. (2016). Model Dan Strategi Pembelajaran Anak Berkebutuhan Khusus Dalam Setting Pendidikan Inklusi. Jurnal Pendidikan Dasar PerKhasa, 2(2), 19-29.

Aline, B. A. A. (2010). Education for advancing the implementation of the Sustainable Development Goals: A systematic approach. The International Journal of Management Education, 5(1), 69-78.

Fannisa, A. R. (2013). The Role Of Shadow Teacher On Giving Education Service For Special Students In The Inclusive School SD N Giwangan Yogyakarta.
Jurnal Widia Ortodidaktika, 3(2), 5161.

Garnida, E. (2015). Peran Guru Pada Sekolah Inklusi. Pustaka Pelajar.

Hamalik, O. (2014). Pendidikan Inklusi. Ghalia Pustaka.

Lattu, D. (2012). Peran Guru Bimbingan dan Konseling pada Sekolah Penyelenggara Pendidikan Inklusi. Jurnal Bimbingan Dan Konseling Terapan, 2(1), 20-28.

Robinson, D. (2017). Effective inclusive teacher education for special educational needs and disabilities: Some more thoughts on the way forward. The International Journal of Teaching and Teacher's Education, $4(2), 78-85$.

Supena, A. (2016). Model Pendidikan Inklusif Untuk Siswa Tunagrahita Di Sekolah Dasar. Jurnal Parameter, 29(2), 67-75. 